\title{
SUPPLEMENT No. 1
}

\author{
BIOSOCIAL ASPECTS OF RACE \\ Edited by G. A. HARRISON and J. PEEL \\ 202 pp. $\mathbf{f 3 . 0 0}$ (U.S.\$8.50)
}

List of contents and authors:

General Introduction by A. S. Parkes. Limitations to Genetic Comparison of Populations by J. M. Thoday. Natural Selection and Population Diversity by A. C. Allison. Ethnic, Caste and Genetic miscegenation by F. S. Hulse. Race, Genetics and Growth by D. F. Roberts. Racial and Inter-racial Differences in Work Capacity by K. Lange Andersen. Ethnic Differences in Sensory Perception by Hans Kalmus. Contributions of Ability and Attainment Testing in Africa to a General Theory of Intellect by $\mathbf{S}$. $\mathbf{H}$. Irvine. Comment. Olympiad Festival of the Nations, 1936 by Hans Kalmus. Population Prospects for Regions of the World by Wallis Taylor. Differential Fertility Among Immigrants to England and Wales and Some Implications for Population Projections by Jean Thompson. The Galton Lecture 1968: The Race Concept in Human Biology by G. Ainsworth Harrison. Race as a Social Category by John Rex. Race, Pluralism and Nationalism in the British Caribbean by Ivar Oxaal. The Role of the Settlement Area in British Race Relations by M. H. Lyon. Cognitive Aspects of Prejudice by Henri Tajfel.

\section{SUPPLEMENT No. 2}

\section{BIOSOCIAL ASPECTS OF SEX \\ Edited by G. A. HARRISON and J. PEEL 164 pp. $€ 2.50$ (U.S.\$7.00)}

List of contents and authors:

General Introduction by A. S. Parkes. Cytogenetics and Sex Determination in Man and Animals by C. E. Ford. Sex Differences at Puberty by W. A. Marshall. Aspects of Homosexuality by D. J. West. The Search for Genetic Variability of the Sex Ratio by A. W. F. Edwards. Factors Affecting the Sex Ratio in Large Populations by M. S. Teitelbaum. Sex Differences in Age at Marriage by P. R. Cox. The Social Images of Man and Woman by Rosemary Firth. A Comparison of the Academic Performance of Male and Female Students in Schools and Universities by R. R. Dale. The Comparative Employability of Men and Women in Different Industries by B. T. Davies. The Galton Lecture 1969: Women in Academic Life by Kathleen M. Kenyon. Sex Differences in Divorce Behaviour by Robert Chester. Sex, Crime and Society by Frances Heidensohn. Sex Differences in the Neurotic Reactions of the Aged by K. Bergmann. Which is the Weaker Sex? by D. M. Potts.

\section{SUPPLEMENT No. 3}

\section{BIOSOCIAL ASPECTS OF HUMAN FERTILITY \\ Edited by ALAN S. PARKES, JOHN PEEL and BARBARA THOMPSON 143 pp. $€ 3.00$ (U.S.\$8.50)}

List of contents and authors:

General Introduction by P. R. Cox. Coordination of the Reproductive Processes by G. W. Harris. Environmental Influences on Human Fertility by Alan S. Parkes. Biosocial Aspects of Multiple Births by P. P. S. Nylander. Human Fertility in Global Perspective by D. M. Potts. Cultural Explanations of Fert ility Differences by J. Clyde Mitchell. Some Social Determinants of Recent Trends in Brit ish Fertility by Joan Busfield and Geoffrey Hawthorn. Family Structure and Educational Achievement by David Oldman, Bill Bytheway and Gordon Horobin. The Galton Lecture 1970: The Obstetrician and Society by Sir Dugald Baird. Domiciliary Family Planning Services: A Reappraisal by P. F. Selman. The Unwanted Pregnancy by Peter Diggory. Sex Education in Schools-Why and How? by K. John Dennis.

\section{PUBLISHED BY THE GALTON FOUNDATION}

The Journal of Biosocial Science, P.O. Box 32, Commerce Way, Colchester CO2 8PH, England 